\title{
MANAGING THE YelLOW RIVER: Questions of Borders, Boundaries and Access
}

\section{Transforming Cultures eJournal, \\ Vol. 1 No. 2, June 2006 http://epress.lib.uts.edu.au/journals/TfC}

\section{Michael Webber, Jon Barnett, Brian Finlayson \& Mark Wang School of Anthropology, Geography and Environmental Studies The University of Melbourne}

\section{Introduction}

The Yellow River basin is the site of myriad water resource problems. The Yellow River has natural geomorphological characteristics that include seasonally variable flow, very high sediment load, and the capacity to flood with devastating effect. However, people have long sought to harness the water of the Yellow River to their own industrial and agricultural ends, so as to attain the things that they value, like good health, economic growth, and employment. Intensive human use of the basin now poses new managerial problems.

The Yellow River's problems thus now include water scarcity, pollution, and flood risk. In 1997 there were 226 'no flow' days, when the River failed to reach the sea; the dry point started up to $700 \mathrm{~km}$ inland (Jun 2004). This is not part of the natural flow regime of the Yellow River, which rarely ceased to flow before 1992. The Yellow River is also one of China's most polluted rivers. ${ }^{1}$ While a major breach of the levees has been averted since the People's Republic was founded in 1949, there is each year significant flooding in the Yellow River basin. The threat of a major levee failure is real and millions of lives and vast sums of capital investment will be lost in such an event, or if one of the many dams along its length fails. ${ }^{2}$

\footnotetext{
${ }^{1}$ Lohmar, B., Wang, J., Rozelle, S., Huang, J. \& Dawe, D. (2003) China's Agricultural Water Policy Reforms. Washington: United States Department of Agriculture; State Environmental Protection Administration (SEPA) Report on the State of the Environment in China 2002. Beijing: Environmental Information Center (SEPA).

${ }^{2}$ Li, S. \& Finlayson, B. (1993) "Flood Management on the Lower Yellow River: Hydrological and Geomorphological Perspectives", Sedimentary Geology 85(1-4): 285-288; Mei, C. \& Dregne, H. (2001) "Review Article: Silt and The Future Development of China's Yellow River", The Geographical Journal 167: 7-22.
} 
In this paper, we characterise the problems of the Yellow River in order to assess the significance of borders, boundaries and access in understanding the management of water. Events and conditions in particular localities have local causes; and in this sense the bounding of regions is significant. Yet borders and boundaries are permeable, permitting causes also to derive from conditions in neighbouring and distant regions. Furthermore, places have causes at a larger scale, such as the nation, since borders, like the regions they bound, are hierarchical and scaled.

The management of the Yellow River reflects the complex, unstructured interaction of the global economy, China's central government, its regional formations and systems of environmental management. Each nudges the others in particular directions before being nudged in turn. In each region, systems of environmental management compete with each other and with influences from markets, other arenas of state planning, nepotism and local corporatism. The result of this competition depends on influences from the global economy, on stimuli from other regions within China, and above all on the pre-existing regional structure of individual, sectional and class interests. The effects are a new division of activities between the various ways of organising social life within the region and so a new structure of interests, a rescaling of powers between local, provincial and central authorities, and new impacts on global and other regional economies. The central government supervises and sets terms by defining the boundary conditions for interregional and international pressures, the allowable forms of management and the competition between them. Yet the power of the central government to manage this process itself depends on the evolution of the system.

This interpretation of regional environmental management in China reflects on the dynamics of place, and thus on the appropriate scale and form of borders. However, environmental management is also a discourse, the terms of which set boundaries within which social actors may identify problems and discuss allowable solutions. In China this discourse is dominantly one of science and engineering. It identifies the problems of the Yellow River as constrained - spatially constrained (to the basin) and causally constrained (to certain technical problems of industrial and agricultural demand and use). However, the recent history of interaction of economic change and water resource problems in the Yellow River basin suggests that technical solutions implemented within the basin may not be sufficient, and that social solutions and integrated water 
resource management at the national level may also be needed. In other words, in both the conceptual and the spatial sense, some borders must be respected but others inhibit understanding.

The paper has two principal sections. In the first, we trace the emergence of the problems of the Yellow River by linking the changing condition of the River to the economic transition that has been underway in China since 1978. After this groundwork, we turn in the second section to identify some of the key issues involved in managing the Yellow River. This discussion illustrates the interaction of local (within border) and larger scale (hierarchical and cross scale) issues and reveals the manner in which the constraints of the existing discourse conceal non-technical solutions. We conclude by reflecting on the manner in which the management of the River reveals national priorities and goals.

\section{The Yellow River}

Since the late 1970s the Chinese government has approved and sometimes initiated a set of incremental policy experiments. Largely concerned to raise the efficiency with which people produce and trade, this transition has nevertheless had profound effects on social life and environmental conditions. Its effects on water resources were largely unintentional and unanticipated. Evidence of these problems has emerged since the early 1990s, yet understanding of their extent, causes, and solutions is far from complete.

\subsection{China's Economic Transition}

The economic reforms in China since 1978 have entailed a shift away from central economic planning towards more market-oriented forms of economy that include state, collective, and private forms of business. This transition has been endogenously driven, and has occurred through gradual, regular and incremental adjustments in institutions.

China's transition has involved moves to 'open up' the economy to international markets. The changes have seen increased foreign direct investment ${ }^{3}$ and the marketisation of production and distribution systems. In almost all sectors of

\footnotetext{
${ }^{3}$ Wang, M., Webber, M. \& Zhu, Y. (2002a) "Managed Openness: Opening China's Door'” in Webber, M., Wang, M. \& Zhu, Y. (eds.) (2002) China's Transition to a Global Economy. New York: Palgrave Macmillan.
} 
production, including agriculture, state-directed production has now been replaced by market-directed production. The Household Responsibility System (HRS) led to increased agricultural productivity, increased total output, and increased production of vegetables, meat and other higher value farm products. The market now is the largest determinant of household farm production, and more than half of agricultural income is earned from cash sales of farm products. ${ }^{4}$ Rural industrialisation was also a consequence of the HRS.

China is now a set of competing economic systems: centralised political control coexists with market-oriented firms; state-owned enterprises coexist with capitalist foreignfunded firms. State-owned and private enterprises compete to attract resources (including labour and land), and to sell their products or services; individuals now compete for jobs and choose among different forms of activity; and central and regional governments can choose among different systems depending on their capacity to dispense revenues or power, to ameliorate social conflict, or to deliver on the promise of economic growth. ${ }^{5}$ The effect has been a new division of activities between the various ways of organising social, political and economic life within China, ${ }^{6}$ including countless changes in water use.

\subsection{The Household Responsibility System}

The HRS created the opportunity for farmers to expand their incomes by intensifying agricultural production. ${ }^{7}$ This included increased consumption of irrigation water, particularly in north China, leading to increased withdrawals of both surface and groundwater. Fertiliser use increased by $260 \%$ between 1980 and $2002,{ }^{8}$ causing increased water pollution in parts of the Yellow River basin. Intensification of

\footnotetext{
${ }^{4}$ Webber, Wang, \& Zhu (2002a: 61-92).

${ }^{5}$ Ibid.

${ }^{6}$ Webber, M., Wang, M. \& Zhu, Y. (2002b) “Knocking on WTO’s Door” in Webber, Wang \& Zhu (eds.) (2002).

${ }^{7}$ Blaikie, P. (1985) The Political Economy of Soil Erosion in Developing Countries. London: Longman; Muldavin, J. (1998) "Agrarian Change in Contemporary Rural China", in Szelenyi, I. (ed.) Privatizing the Land. Rural Political Economy in Post-Communist Societies. London: Routledge; Muldavin, J. (2000) "The Paradoxes of Environmental Policy and Resource Management in Reform-Era China", Economic Geography 76(3): 244-71.

${ }^{8}$ FAOSTAT (2004) Agricultural Data. Food and Agriculture Organization Of The United Nations: Statistical Data. <http://Faostat.Fao.Org> (Last Accessed 16/8/2004.)
} 
production also led to a three-fold increase in the area of land under permanent crops between 1978 and $2002 .^{9}$

High population densities and the more or less equal allocations of land under the HRS together mean that land holdings are small and fragmented, ${ }^{10}$ precluding the possibility of saving water by investing in large-scale irrigation. The low rates of return from farming relative to other opportunities have also constrained investment in sustainable water use. Nevertheless, since 1978 China's agricultural sector has apparently become a more efficient user of water. Between 1980 and 2003 total production of cereals increased by $39 \%$, and there was fourfold increase in production of meat and vegetables. ${ }^{11}$ Yet there seems to have been little increase in the use of water: between 1980 and 1997 agricultural water use increased by less than $4 \%{ }^{12}$ Between 1980 and 1997 agriculture's share of all Chinese water use decreased from $88 \%$ to $72 \%{ }^{13}$ although other estimates put agriculture's share as high as $87 \% .{ }^{14}$ Though agriculture remains the largest user of water in China, the water scarcity problem may be largely a product of the growth of industrial and urban uses which are consuming an increasing share of available water resources, and demanding yet more. ${ }^{15}$

\subsection{Urbanisation and increasing affluence}

In 1978, at the start of transition, China's urban population was officially 80 million. ${ }^{16}$ This had increased to 490 million by $2002^{17}$ - a rate of increase far in excess of national

\footnotetext{
${ }^{9}$ Ibid.

${ }^{10} \mathrm{Hu}, \mathrm{W}$. (1997) "Household Land Tenure Reform in China: Its Impact on Farming Land Use and Agroenvironment”, Land Use Policy 14(3):175-86.

${ }^{11}$ FAOSTAT (2004).

${ }^{12}$ United Nations Development Program (UNDP) (2002) China Human Development Report 2002: Making Green Development a Choice. New York: Oxford University Press; Mei, X. (1999) "Water Shortage and Food Production in China: Issues, Potential, and Solutions". Paper Presented at the USChina Water Resources Management Workshop April 18-22 Tuscon Arizona.

${ }^{13}$ Mei (1999).

${ }^{14}$ Varis, O. \& Vakkilainen, P. (2001) “China's 8 Challenges to Water Resource Management in the First Quarter of the 21st Century”, Geomorphology 41(2-3): 93-104.

${ }^{15}$ Nyberg, A. \& Rozelle, S. (1999) Accelerating China's Rural Transformation. Washington: The World Bank; Yang, H. \& Zehnder, A. (2001) “China's Regional Water Scarcity and Implications for Grain Supply and Trade" Environment and Planning A 33(1):79-95; Bellier, M. \& Zhou, Y. (2003) Private Participation in Infrastructure in China. Issues and Recommendations for the Road, Water and Power Sectors. Washington DC: The World Bank.

${ }^{16}$ Wang et al (2002b).

${ }^{17}$ United Nations Development Program (UNDP) (2004) Human Development Report 2004. Oxford: Oxford University Press.
} 
population growth. Urban growth has contributed to water scarcity problems in China because, as more and more people live within cities and become more affluent, they each consume and demand more water. Urban use has been the fastest growing sector of water use in China, with municipal uses of water increasing by $10.1 \%$ per annum throughout the 1990s. ${ }^{18}$ Beijing's growing demand for water has translated directly into reduced allocations of water to agriculture and rapid decreases in aquifers around the city. ${ }^{19}$

Relative to other regions in China, water is scarce in the Yellow River basin. ${ }^{20}$ Urban uses of water in the basin increased by $245 \%$ between 1980 and $1993,{ }^{21}$ and use is highest in Shanxi, Shaanxi, Henan, and Shandong. ${ }^{22}$ Urban demands are likely to be increasingly influential as urban centres are the basis of political power in China, as in almost every country. This is despite the fact that the welfare of urban residents is rarely as sensitive to changes in water supply as is the welfare of resource-dependent rural people.

As incomes continue to rise there has been a decline in the proportion of cereals being consumed, and an increase in consumption and production of more expensive, higher quality food products, especially animal products. ${ }^{23}$ Between 1979 and 2002, the supply of calories from animal products more than quadrupled, as did meat production; the supply of calories from fruits increased five fold and production of fruits increased more than eight-fold; calorie supply from vegetables quadrupled and production of vegetables increased more than seven-fold. ${ }^{24}$ Increasing production of meat has entailed increased

\footnotetext{
${ }^{18}$ Economy, E. (2004) The River Runs Black: The Environmental Challenge to China's Future. Ithaca: Cornell University Press.

${ }^{19}$ Jun, M. (2004) China's Water Crisis. Norwalk: Eastbridge Books.

${ }^{20}$ Cai, X. \& Rosengrant, M. (2004) “Optional Water Development Strategies for The Yellow River Basin: Balancing Agricultural and Ecological Water Demands" Water Resources Research 40(8): Art No W08S04.

${ }^{21}$ Heilig, G. (1999) Can China Feed Itself? Laxenburg Austria: IIASA CD-Rom.

${ }^{22}$ Yellow River Conservancy Commission (YRCC) (2005a) "Development and Utilization of Water Resources". Retrieved from <http://www.yellowriver.gov.cn/lib/e_hhszy/2002-1223/jj_13362425174.html>

${ }^{23}$ Helig (1999); Tian, W. \& Chudleigh, J. (1999) “China's Feed Grain Market: Development and Prospects", Agribusiness 15(3): 393-409.

${ }^{24}$ FAOSTAT (2004).
} 
production of feed grains, so that between 1991 and 1996, the production of coarse feed grain increased more than any other cereal. ${ }^{25}$

These changes in demand and supply are important for water use since fruits, vegetables, nuts, dairy products and meat are less water efficient (they use more water per calorie delivered) than wheat or corn. That is, fruit, vegetables and animal products are economically more efficient than grains, in the sense that they yield more dollars' worth of output per cubic metre of water applied; but they are less water efficient than grains. Thus, the development of a market economy is leading farmers to become more economically efficient, but less water efficient. Corn is more efficient than wheat, with corn's water efficiency at $1.96 \mathrm{~kg} / \mathrm{m}^{-3} .{ }^{26}$ While the conversion of farmland to horticulture (and fish ponds) has been greatest in the populous southern areas, increased production of non-grain foods has also occurred in the Yellow River basin. For example, in Henan and Shandong food production now includes an increasing proportion of non-grain crops as farmers seek higher economic returns per unit of water used. There has also been an increase in corn production for feed grain. ${ }^{27}$

\subsection{Industrialisation}

Transition led to large-scale industrialisation in some regions of China. Of the 980235 hectares of cultivated land converted for industrial and urban uses between 1988 and 1995, 34\% was converted in the coastal and southern provinces of Shandong, Jiangsu, Zhejiang, Jianxi, Hunan, Fujian, Guandong and Guanxi. ${ }^{28}$ In these regions both the area under cultivation and agricultural output have declined, and industrial water use has trebled. ${ }^{29}$ Nationwide, industrial uses of water doubled between 1980 and 1997, ${ }^{30}$ and again since. ${ }^{31}$ These industrial uses have contributed to increased demand (and therefore increased scarcity) for water, and to water pollution. In particular, the more than 500000 township and village enterprises seem to be exempt in both policy and practice from

\footnotetext{
${ }^{25}$ Tian \& Chudleigh (1999).

${ }^{26}$ Yang \& Zehnder (2001: 92).

${ }^{27}$ Yang \& Zehnder (2001); Yang, H., Zhang, X., Zehnder, A. (2003) "Water Scarcity, Pricing Mechanisms and Institutional Reform in Northern China Irrigated Agriculture", Agricultural Water Management 61(2): 143-61.

${ }^{28}$ Heilig (1999).

${ }^{29}$ Ibid.

${ }^{30}$ UNDP (2002).

${ }^{31}$ Economy (2004).
} 
environmental regulation and their emissions are not monitored, even though they are thought to be responsible for approximately half of all pollution in China. ${ }^{32}$

In the regions where industrialisation has been most rapid there have been the largest declines in allocation of labour, land and finance for agricultural purposes. This shift of capital away from agriculture occurred rapidly in the southern and coastal regions. However, these are also the regions that have the most abundant water resources and are climatically the most suitable for agriculture. This has in turn caused a relocation of agricultural production in China.

\subsection{The Changing Geography of Agriculture}

The areas where industrialisation has been relatively less rapid have taken up the resulting gap in agricultural supply, particularly of less profitable crops such as wheat. However, these areas are generally dry, and three of the five provinces with largest net gains in the area of cultivated land between 1988 and 1995 were in the Yellow River basin (Gansu, Ningxia and Qinghai). These areas cannot meet the gap in supply created by reduced production in the South without using irrigation and fertilisers, leading to overdrawing of groundwater and excessive water pollution. As a proportion of all water use, irrigation use is high in the Yellow River basin. ${ }^{33}$ According to Cai and Rosengrant the area of irrigated land in the basin increased more than nine times between 1950 and 2000. Agriculture accounts for perhaps $80-90 \%$ of all water withdrawals in the basin. ${ }^{34}$

Agriculture has intensified significantly on the North China Plain for four reasons: it is one of the few areas of China in which flat land is abundant; restrictions on migration coupled with a relatively low level of industrialisation mean that people in the North China Plain have had few better income earning opportunities than agriculture; increasing incomes and urbanisation in the South coupled with population growth have increased demand for all kinds of food; and much of this increased demand is not being met by production in the wetter Southeast of the country. So, the North China Plain now

\footnotetext{
${ }^{32}$ Economy (2004); Vermeer, E. (1998) "Industrial Pollution in China and Remedial Policies" The China Quarterly 156 (Special Issue): 952-985.

${ }^{33}$ Heilig (1999).

${ }^{34}$ Cai \& Rosengrant (2004); Heilig (1999); YRCC (2005a).
} 
produces $60 \%$ of China's wheat and $40 \%$ of its corn, ${ }^{35}$ even though the region has only $22 \%$ of China's cultivated land and just $4 \%$ of its water resources. ${ }^{36}$

Intensification of agricultural production on the North China Plain has been achieved principally through increasing irrigation and fertiliser use. ${ }^{37}$ Shandong and Henan are the highest users of fertilisers in China, and use is also high in Shaanxi. ${ }^{38}$ Agriculture in the North China Plain is now nearly totally dependent on irrigation, and the volume of water used for irrigation on the Plain is three or four times annual rainfall. ${ }^{39}$ Much of the water used for irrigation therefore comes from groundwater, extraction of which exceeds groundwater recharge rates. ${ }^{40}$ There is much evidence to suggest that irrigation on the North China Plain is unsustainable. ${ }^{41}$ For example, the water table is reported to be falling by as much as $1 \mathrm{~m} /$ year, ${ }^{42}$ and may have dropped $70 \mathrm{~m}$ in some areas. ${ }^{43}$

\subsection{So: development and water in the Yellow River basin}

The changing geography of agriculture in China, which is driven by the way the 1978 reforms triggered rapid industrialisation in the South and coast, means that agriculture has intensified in the Yellow River basin. Most people in the basin depend on agriculture for their livelihoods, with generally fewer alternative opportunities for income generation than among urban and southern people. ${ }^{44}$ This is reflected, in part, in

\footnotetext{
${ }^{35}$ Yang et al (2003).

${ }^{36}$ Yang \& Zehnder (2001).

${ }^{37}$ Yang \& Zehnder (2001); Pereira, L., Cai, L, \& Hann M (2003) "Farm Water and Soil Management for Improved Water Use in the North China Plain”, Irrigation and Drainage 52(4):299-317.

${ }^{38}$ UNDP (2002).

${ }^{39}$ Zhen, L. \& Routray, J. (2002) “Groundwater Resource Use Practices and Implications for Sustainable Agricultural Development in the North China Plain: A Case Study in Ningjin County of Shandong Province, PR China", Water Resources Development 18: 581-93.

${ }^{40}$ Liu, C. \& Xia, J. (2004) "Water problems and hydrological research in the Yellow River and the Huai and Hai River basins of China” Hydrological Processes 18(12): 2197-2210.

41 Nyberg, A. \& Rozelle, S. (1999) Accelerating China's Rural Transformation. Washington: The World Bank; World Bank (2002) China. Country Water Resources Assistance Strategy. Washington: The World Bank East Asia and Pacific Region; Zhen \& Routray (2002); Yang et al (2003).

${ }^{42}$ World Bank (2002).

${ }^{43}$ Foster, S, Garduno, H., Evans R, Olson, D. \& Tian, Y. (2004) "Quaternary Aquifer of the North China Plain - Assessing and Achieving Groundwater Resource Sustainability” Hydrogeology Journal 12(1): 8193; Varis, O. \& Vakkilainen, P. (2001) "China's 8 Challenges to Water Resource Management in the First Quarter of the 21st Century”, Geomorphology 41(2-3): 93-104.

${ }^{44}$ Wu, B. \& Pretty, J. (2004) "Social Connectedness in Marginal Rural China: The Case of Farmer Innovation Circles in Zhidan, North Shaanxi", Agriculture and Human Values 21: 81-92; Yang et al (2003).
} 
data about development in the basin: of the nine provinces in the Yellow River, seven are in the lower half of China's 31 provinces when they are ranked according to the human development index (HDI, a composite measure of life expectancy, education, and income). ${ }^{45}$ Levels of human development in these provinces are less than the Chinese average, and are equivalent to those of Tajikistan, Mongolia and Egypt. ${ }^{46}$ The principal cause of these relatively low levels of human development is low production (by value) in most provinces: with the exception of Shandong all the Yellow River provinces rank lower in GDP per capita than they do in the overall HDI. Household incomes, particularly in rural areas, are low. This means that access to water is critical to the livelihoods of most of the $\sim 130$ million rural people who depend on water from the Yellow River basin.

So, while industrial water use and pollution in the Yellow River basin are both growing, and while urban demands are rising, it is farmers who are the group most sensitive to water problems. The implications of changes in farmer's entitlements to useable water (a function of quantity, cost, and quality) may be profound, not just for individual rural households, but also for North China, and perhaps even China as a whole. Indeed, it may be prudent for policymakers to consider these farmers as the most important stakeholders in water reforms in the basin. Solutions require an understanding of the vulnerability of rural livelihoods to changes in entitlements to water.

\section{Questions of borders, boundaries and access}

It is the interaction of regional conditions, developments in other provinces, and supraregional policies that defines the nature of and the solutions to the problems of managing the water supply of the Yellow River. However, the discourses about water in the Yellow River basin restrict people's understanding of these problems and their potential solutions. We now identify some of the key issues involved in managing the Yellow River, illustrating the interaction of local and larger scale issues and of discourse and management.

\footnotetext{
${ }^{45}$ UNDP (2002).

${ }^{46}$ Ibid.
} 


\subsection{Scale, boundaries and governance regimes}

There are many bodies responsible for various aspects of water regulation and management in the Yellow River basin. The Ministry of Water Resources (MWR) is a principal responsible State body, though it delegates some responsibility to the Yellow River Conservancy Commission, irrigation districts, and the Provincial Water Resource Bureaus and Offices. ${ }^{47}$ At the sub-provincial level there are prefecture, county and township water management stations, and at the village level, there are water management committees. ${ }^{48}$ Other State agencies are also involved in water resource management. Whereas water supply is the principal concern of the Ministry of Water Resources and its subordinate agencies, water pollution is largely the concern of the State Environmental Protection Administration (SEPA). Other national level agencies involved are the Ministry of Geology and Mining, the Ministry of Agriculture, the State Forest Administration, the State Development Planning Commission, the State Economic and Trade Commission, the Ministry of Construction and the State Price Bureau. $^{49}$ Effective water management is therefore contingent on a high degree of cooperation among agencies and between agencies at different administrative levels. However, this cooperation rarely occurs. ${ }^{50}$ The dichotomy of power and authority in Chinese is referred to as tiaotiao-kuaikuai fenge or the conflict between the vertical tiaotiao lines of authority and horizontal kuaikuai lines of authority and the division between these within the bureaucracy. (Of course in every country there is a lack of coordination across government agencies for the purposes of sustainable development.)

An improved governance regime is critical to managing the Yellow River basin's problems. ${ }^{51}$ If governance means the mechanisms through which people and groups express their concerns, negotiate their differences, exercise their obligations and ensure fulfilment of their rights, then governance in this sense necessarily includes people and their regular practices, rules, laws, behavioural norms, conventions and organisations (institutions), as well as governments. However, improved governance in this sense may

\footnotetext{
${ }^{47}$ Lohmar, B., Wang, J., Rozelle, S., Huang, J. \& Dawe, D. (2003) China's Agricultural Water Policy Reforms. Washington: United States Department of Agriculture.

${ }^{48}$ Nyberg \& Rozelle (1999).

${ }^{49}$ Lohmar et al (2003); UNDP (2002).

${ }^{50}$ Lohmar et al (2003); UNDP (2002); Varis \& Vakkilainen (2001); Wang (2003).

${ }^{51}$ Economy (2004); UNDP (2002); Vermeer (1998); Wang, X. \& Ongley, E. (2004) "Transjurisdictional water pollution disputes and measures of Resolution: Examples from the Yellow River Basin, China", Water International, 29(3): 282-289; World Bank (2002).
} 
be difficult to achieve: for example, it is difficult to couple local people and their resource management institutions to larger scale institutions without losing the advantages of local 'fit'. ${ }^{52}$ It is also clear that improved governance in this sense is outside the prevailing discourse: at the second International Yellow River Forum in Zhengzhou in October 2005 fewer than one per cent of the papers in the conference proceedings discussed such issues. ${ }^{53}$

Given the existing complexity of actors in water resource management in the Yellow River basin, it may be desirable to move towards a system of nested, cross scale institutions in which responsibility for making, implementing, monitoring and adapting policies rests with the most appropriate level. Folke et al (1998) call such a system a 'nested system of governance'; Ostrom refers to a similar idea as a 'polycentric' governance system. ${ }^{54}$ Key issues in refining the current system to become this more nested and polycentric ideal include: balancing the degree of autonomy of institutions with a need for overall coordination; spreading power throughout various institutions in the system; clarifying roles and responsibilities of institutions; identifying aggregate outcomes that are not allowed; making explicit who is allowed to use resources, where and when; determining who is allowed to make decisions and how decisions are to be made; and establishing clear channels of communication throughout the governance system. ${ }^{55}$ Such a system of governance - that collects and distributes information, negotiates the definition of problems, agrees policy goals and sets measurable policy targets, monitors policy implementation and outcomes, and adapts policies as required is far more important than actual policies. ${ }^{56}$

\footnotetext{
${ }^{52}$ Folke, C., Pritchard, L., Berkes, F., Colding, J. \& Svedin, U. (1998) The Problem of Fit Between Ecosystems and Institutions IHDP Working Paper No: 2 International Human Dimensions Programme on Global Environmental Change: Bonn.

$<$ http://www.ihdp.uni-bonn.de/html/publications/workingpaper/wp02m.htm>

${ }^{53}$ YRCC (2005b) Proceedings of the Second International Yellow River Forum on Keeping Healthy Life of the River Zhengzhou: YRCC.

${ }^{54}$ Ostrom, E. (2001) "Vulnerability and polycentric governance systems", IHDP Update 3/01: 1-4.

${ }^{55}$ Folke et al (1998); Gunderson, L., Holling, C. \& Light, S. (eds.) (1995) Barriers and Bridges to the Renewal of Ecosystems and Institutions. New York: Columbia University Press; Handmer, J. \& Dovers, S. (1996) "A typology of resilience: Rethinking institutions for sustainable development", Industrial and Environmental Crisis Quarterly 9(4): 482-511; Ostrom (2001).

${ }^{56}$ Dovers, S. (1995) "Information, sustainability and policy", Australian Journal of Environmental Management, 2(3):142-156.
} 


\subsection{Choice of policy instruments}

Once established, the governance system decides on policy goals and targets, and then selects instruments for implementing policy. Too frequently the choice of policy instruments is framed as a debate between regulation and market based mechanisms, ${ }^{57}$ and this is true of discussions about solutions to water problems in the Yellow River basin. Yet there are many more policy instruments than these. Dovers (1995) lists 13 instruments for implementing policy, including: education and training; consultation, mediation and negotiation; agreements and conventions; regulation by the State; selfregulation by users; community involvement in management; removal or adjustment of distorting policies; and market mechanisms. Even market mechanisms include a variety of instruments, including taxes, user charges, subsidies, penalties, tradeable permits, and performance or assurance bonds. ${ }^{58}$ This variety of policy instruments suggests that there are many choices for achieving policy goals and that there is likely to be an effective instrument for each particular water use and user. Regardless of the instrument chosen, all policy instruments are best seen as information that requests, orders, encourages, warns, and creates incentives for desirable forms of action. ${ }^{59}$

Commonly, the selection of policy instruments depends on the biases of agencies and advocates, and on traditional ways of doings things. ${ }^{60}$ Yet there are more rational criteria for selecting the best policy instrument, including: equity - since the distributional outcomes of one instrument choice can undermine larger policy goals; political feasibility - since some instruments may not be accepted by groups and/or users with power; institutional feasibility - since some institutions may not be capable of implementing some instruments (for various reasons ranging from legal mandate through to staff skills); the ability to monitor progress of the instrument's effectiveness (or not); the degree to which an instrument can be enforced; and the degree to which the

\footnotetext{
${ }^{57}$ Dovers, S. \& Gullett, W. (1999) "Policy choice for sustainability: marketization, law and institutions", in K. Bosselmann and B. Richardson (eds.) Environmental Justice and Market Mechanisms, London: Kluwer Law International, pp. 110-128; Fiorino, D. (1995) Making Environmental Policy. Berkeley and Los Angeles: University of California Press.

${ }^{58}$ Dinar, A., Rosegrant, M.W. \& Meinzen-Dick, R. (1997) "Water allocation mechanisms - principles and examples", Policy Research Working Paper WPS1779. World Bank Publications. <http://wwwwds.worldbank.org/servlet/WDS_IBank_Servlet?pcont=details\&eid=000009265_3970909143002>

${ }^{59}$ Dovers \& Gullett (1999).

${ }^{60}$ Ibid.
} 
operation of an instrument and the reasons for its use can be communicated to those with which it engages. ${ }^{61}$

Policy instruments are not always transferable between cultures. Cassar, for example, identifies the ineffectiveness of regulation in the management of Ramsar-listed wetland sites in China because of people's unwillingness to deliberately participate in the legal system. ${ }^{62}$ Likewise, price mechanisms that derive from practices in liberal-democratic societies in which farmers behave individualistically may be incompatible with the organisation of Chinese villages in which irrigation infrastructure is still communal and in which choices about irrigation are still often made in concert with neighbours and driven by the water supply decisions of such bodies as the YRCC. The localisation of appropriate instruments is another arena of management that lies outside discourses of water in China.

\subsection{Access: the price of agricultural water in the Yellow River basin}

The official discourse within China and among its advisors suggests that unsustainable water use in the basin is largely due to the low cost of irrigation, and propose that commodity pricing would encourage more efficient water use in rural areas. ${ }^{63}$ The principal effect of this policy will be to increase the cost of inputs into farming. Farmers' responses to changes in the price of irrigation water depend on its price. ${ }^{64}$ If water is cheap, a price rise does not cause farmers to change their cropping decisions or irrigation practices, so they simply pay more for the same amount of water. At higher prices, farmers respond to price increases by substituting new crops (that demand less water or produce higher incomes per unit of applied water) for their traditional crops. Farmers still lose income, but water is saved. Then at very high prices, farmers use almost no water for irrigation anyway, so price increases have little effect on their cropping decisions or irrigation practices.

\footnotetext{
${ }^{61}$ Dovers (1995).

${ }^{62}$ Cassar, A. (2005) Implementing International Environmental Law in Domestic Environmental Management: Wetlands of International Importance in Australia and the People's Republic of China. PhD Thesis, School of Anthropology, Geography and Environmental Studies, The University of Melbourne.

${ }^{63}$ Nyberg \& Rozelle (1999); UNDP (2002); World Bank (2002); YRCC (2005b).

${ }^{64}$ Yang et al (2003).
} 
Those whose livelihoods most depend upon water (farmers) are typically poor and their incomes may not support a sudden shift to market-valuation. The net effect of increased production costs is to transfer income out of agriculture, so that small farmers become uncompetitive and production becomes dominated by fewer but larger farms, with a net loss of employment in agriculture, increased number of landless labourers and ruralurban migration. So, the social impacts of water pricing are significant, and the identification of winners and losers from such a policy - including the implications for China as a whole - is important. If pricing is to be the regulatory tool, it is important to determine a price of rural water that avoids adverse social consequences but achieves gains in efficiency.

Pricing is merely one way of rationing farmers' entitlement to water. Others include consultation, negotiation, convention, State regulation, user self-regulation and community management, ${ }^{65}$ though they are outside the terms of current debates in China. The implications of changes in farmer's entitlements to useable water may be profound, not just for individual rural households, but also for North China, and perhaps even China as a whole.

\subsection{Regional borders: south-north water transfers}

The South-North Water Transfer Scheme involves constructing a network of canals to divert water from the Yangtze (south) to the Yellow River Basin (north). It began in December 2002 and is expected to take fifty years to complete at a cost of US\$58 billion. The economic costs of the project are twice those of the Three Gorges Dam, ${ }^{66}$ and should these costs ever be fully incorporated into the price of water North China's farmers may be no longer competitive. ${ }^{67}$

Bezlova (2004) estimates that 40-50 billion cubic metres of water could be transferred annually. At 2004 ADB interest rates on US dollar denominated loans (6.18\%), the annual interest bill on the project is nearly \$US3.6 billion, or about 8 cents per cubic

\footnotetext{
${ }^{65}$ Dovers (1995).

${ }^{66}$ Bezlova, A. (2004) "Water woes threaten to dry out north", Inter Press Service English News Wire, June 10. At Three Gorges Probe:

$<$ http://www.threegorgesprobe.org/tgp/index.cfm?DSP=content\&ContentID=10673>

${ }^{67}$ Shu, G., Zhou, Y., Zhang, M. \& Smallwood, K. (2001) “A sustainable agro-ecological solution to water shortage in the North China Plain (Huabei Plain)", Journal of Environmental Planning and Management 44(3): 345-55.
} 
metre, ten-twenty times the national average price of water for agriculture. ${ }^{68}$ Estimates of the yield benefits of irrigation vary widely, depending on location and season; on the loess plateau and the north China plain, $1 \mathrm{~mm}$ of irrigation on winter wheat might yield $5.5-10.5 \mathrm{~kg} /$ ha. ${ }^{69}$ Since ten cubic metres yields $1 \mathrm{~mm}$ of irrigation over 1 ha at $100 \%$ efficiency and wheat is worth about $\$ 0.2$ per $\mathrm{kg}, 80$ cents worth of water applied as irrigation yields between $\$ 1.10$ and $\$ 2.20$ per ha extra wheat. At the current average of $40 \%$ efficiency, it requires $\$ 2.00$ of water to gain this increment of yield. Given that these calculations do not include non-optimal applications of water, other production costs and maintenance, it is evident that the south-north transfer cannot resolve farmers' entitlement failures, unless the water is not going to be priced to cover costs. (Of course, fruit and vegetables require less water to gain a dollar increment in output.)

If this conclusion is correct, then the place of the south-north transfer in China's development policy needs to be questioned. If at least some of the water is to be used for agriculture, then it will have to be subsidised; so commitment to the scheme signals that the state intends to subsidise farmers, keeping them in rural areas and producing food - for reasons of national food security or to prevent mass migration of pauperised farmers to the cities, perhaps. If most of the water is sold to urban-industrial consumers, then the scheme will increase their total entitlement without reducing that of farmers. There may, too, be other benefits - for example, associated with lower flood risks on the Yangtze River and hydro-power development. In other words, the State's endorsement of this project implies a commitment to keep China the way it is: China can more or less feed itself; most peasants remain on the land; urbanisation and industrialisation can proceed at the current pace.

\section{Conclusions}

There do not seem to be any simple solutions to water problems in the Yellow River basin. If nothing else, our analysis suggests that at least some solutions to water

\footnotetext{
${ }^{68}$ Yang et al (2003).

${ }^{69}$ Kang, S.Z., Zhang, L., Liang, Y.L. \& Cai, H.J. (2002) "Effects of limited irrigation on yield and water use efficiency of winter wheat on the Loess Plateau of China", in McVicar, T.R., Li, R., Walker, J., Fitzpatrick, R. \& Wand Liu, C.M. (eds.) Regional Water and Soil Assessment for Managing Sustainable Agriculture in China and Australia ACIAR Monograph No 84:105-116; Zhang, H., Wang, X., You, M. \& Liu, C. (1999) "Water - yield relations and water-use efficiency of winter wheat in the North China Plain”, Irrigation Science 19: 37-45.
} 
problems in the Yellow River lie outside the basin and beyond the realm of science or technology.

There is a lot of interest in increasing the cost of water, particularly to farmers, as a way of encouraging more efficient use of water in the Yellow River Basin. However, bearing in mind the relative poverty of most farmers in the basin, and that water costs are already high in many places, ${ }^{70}$ higher water prices may merely raise poverty by increasing farmers' production costs. ${ }^{71}$ If it is to be implemented, water pricing will require careful central government control in establishing, maintaining, and monitoring water markets and their potential social repercussions. In other words, management solutions require local understanding rather than the simple import of American, Australian and European practices.

Some important factors in the livelihoods of farmers and their use of water are also determined by the central government. Increasing the profitability of farming is as important as increasing water price. Because farming is not the most profitable activity for people in rural areas, they do not invest in it. If more income could be earned then households might invest to sustain their businesses. Perhaps the central government should increase the length of land leases - and provide firm guarantees of tenure - to encourage capital investment, and to consolidate land holdings to create continuous blocks. Perhaps cooperative farming based on pooled land would share the costs of irrigation whilst achieving some economies through scaling up of irrigation projects. Clear property rights over small irrigation systems would encourage towns and villages to maintain and improve them. ${ }^{72}$ Increasing farm profits could also be achieved through more direct measures such as a non-production based transfer to farmers in water scarce regions, low rates of taxation to increase profitability, subsidies on certain forms of production to encourage farming in the most ecologically suitable places, and subsidies on water conservation technologies.

National-level water planning may also help to locate some of the most water intense forms of agricultural and industrial production in the places where water is most

\footnotetext{
${ }^{70}$ Yang et al (2003).

${ }^{71}$ Lohmar et al (2003); Yang et al (2003).

${ }^{72}$ Lohmar et al (2003).
} 
abundant (the South and East). During the transition, power was decentralised to provincial and lower level governments, whose increasingly autonomous development plans in effect set these jurisdictions in competition with each other for the available water resources. An effective water governance system requires national coordination to clarify the jurisdictions, roles, and authorities of various central government agencies, river valley commissions, provincial governments, municipalities, counties, irrigation districts, and water management committees. ${ }^{73}$ The problems of the Yellow River are national and resolution of them requires national initiatives.

These conclusions can be re-expressed within the terms of the debate in this volume over borders. At one level, borders are spatial; and we have argued that understanding and effective management are constrained by thinking solely in terms of the Yellow River basin. These spatial borders need to be re-imagined as both permeable and hierarchical, and liable to rescaling as development alters the relations between places. At another level, though, are the constraints that limit the discourses about the problems and the management of the Yellow River. These are borders that need to be broken down, so that the relations between proposed solutions and broader social considerations are more properly understood.

\section{References}

Bellier, M. \& Zhou, Y. (2003) Private Participation in Infrastructure in China. Issues and Recommendations for the Road, Water and Power Sectors. Washington DC: The World Bank.

Bezlova, A. (2004) "Water woes threaten to dry out north", Inter Press Service English News Wire, June 10. At Three Gorges Probe, $<$ http://www.threegorgesprobe.org/tgp/index.cfm?DSP=content\&ContentID=106 $73>$

Blaikie, P. (1985) The Political Economy of Soil Erosion in Developing Countries. London: Longman.

Cai, X. \& Rosengrant, M. (2004) “Optional Water Development Strategies for The Yellow River Basin: Balancing Agricultural and Ecological Water Demands", Water Resources Research 40(8): Art No W08S04.

Carter, C.A., Zhong, F.N. \& Cai, F. (1996) China's Ongoing Agricultural Reform. San Francisco: 1990 Institute.

Cassar, A. (2005) Implementing International Environmental Law in Domestic Environmental Management: Wetlands of International Importance in Australia

\footnotetext{
${ }^{73}$ Economy (2004); Lohmar et al (2003); Nyberg \& Rozelle (1999).
} 
and the People's Republic of China. Ph.D. Thesis, School of Anthropology, Geography and Environmental Studies, The University of Melbourne.

Chen, C., Findlay, C., Watson, A. \& Zhang, X. (1994) "Rural Enterprise Growth in a Partially Reformed Chinese Economy”, in Findlay C, Watson A \& Wu X (Eds) Rural Enterprises in China. New York: St Martin's Press.

Dinar, A., Rosegrant, M.W. \& Meinzen-Dick, R. (1997) "Water allocation mechanisms - principles and examples", Policy Research Working Paper WPS1779. World Bank Publications.

Dovers, S. \& Gullett, W. (1999) "Policy choice for sustainability: marketization, law and institutions", in Bosselmann, K. \& Richardson, B. (eds.) Environmental Justice and Market Mechanisms. London: Kluwer Law International.

Dovers, S. (1995) "Information, sustainability and policy", Australian Journal of Environmental Management, 2(3):142-156.

Economy, E. (2004) The River Runs Black: The Environmental Challenge to China's Future. Ithaca: Cornell University Press.

FAOSTAT (2004) Agricultural Data. Food and Agriculture Organization Of The United Nations: Statistical Data. Last Accessed 16/8/2004, $<$ http://Faostat.Fao.Org $>$

Findlay, C, Watson, A \& Wu, X, (eds.) (1994) Rural Enterprises In China. New York: St Martin's Press.

Fiorino, D. (1995) Making Environmental Policy. Berkeley and Los Angeles: University of California Press.

Folke, C., Pritchard, L., Berkes, F., Colding, J. \& Svedin, U. (1998) The Problem of Fit Between Ecosystems and Institutions IHDP Working Paper No: 2 International Human Dimensions Programme on Global Environmental Change: Bonn.

Foster, S., Garduno, H., Evans, R., Olson, D. \& Tian, Y. (2004) "Quaternary Aquifer of the North China Plain - Assessing and Achieving Groundwater Resource Sustainability" Hydrogeology Journal 12(1): 81-93.

Gunderson, L., Holling, C. \& Light, S. (eds.) (1995) Barriers and Bridges to the Renewal of Ecosystems and Institutions. New York: Columbia University Press.

Handmer, J. \& Dovers, S. (1996) “A typology of resilience: Rethinking institutions for sustainable development", Industrial and Environmental Crisis Quarterly 9(4): 482-511.

Heilig, G. (1999) Can China Feed Itself? Laxenburg Austria: IIASA CD-Rom. $<\mathrm{http}$ //www.ihdp.uni-bonn.de/html/publications/workingpaper/wp02m.htm> $<$ http://www.threegorgesprobe.org/tgp/index.cfm?DSP=content\&ContentID $=106$ $73>$

$<$ http://www.yellowriver.gov.cn/lib/e_hhszy/2002-12-23/jj_13362425174.html>

$<$ http://www-wds.worldbank.org/servlet/>

Hu, W. (1997) "Household Land Tenure Reform in China: Its Impact on Farming Land Use and Agroenvironment", Land Use Policy 14(3):175-86.

Jun, M. (2004) China's Water Crisis. Norwalk: Eastbridge Books.

Kang, S.Z., Zhang, L., Liang, Y.L. \& Cai, H.J. (2002) "Effects of limited irrigation on yield and water use efficiency of winter wheat on the Loess Plateau of China", in McVicar, T.R., Li, R., Walker, J., Fitzpatrick, R. \& Wand Liu, C.M. (eds.) 
Regional Water and Soil Assessment for Managing Sustainable Agriculture in China and Australia ACIAR Monograph No 84.

Krusekopf, C. (2002) "Diversity in Land-Tenure Arrangements under the Household Responsibility System in China", China Economic Review 13(2-3): 297-312.

Li, S. \& Finlayson, B. (1993) "Flood Management on the Lower Yellow River: Hydrological and Geomorphological Perspectives", Sedimentary Geology 85(14): $285-288$.

Liu, C. \& Xia, J. (2004) "Water problems and hydrological research in the Yellow River and the Huai and Hai River basins of China" Hydrological Processes 18(12): 2197-2210.

Lohmar, B., Wang, J., Rozelle, S., Huang J \& Dawe, D. (2003) China's Agricultural Water Policy Reforms. Washington: United States Department of Agriculture.

Mei, C. \& Dregne, H. (2001) "Review Article: Silt and The Future Development of China's Yellow River", The Geographical Journal 167: 7-22.

Mei, X. (1999) "Water Shortage and Food Production in China: Issues, Potential, and Solutions". Paper Presented at the US-China Water Resources Management Workshop April 18-22 Tuscon Arizona.

Muldavin, J. (1998) “Agrarian Change in Contemporary Rural China”, in I. Szelenyi (ed.) Privatizing the Land. Rural Political Economy in Post-Communist Societies. London: Routledge.

- (2000) "The Paradoxes of Environmental Policy and Resource Management in Reform-Era China", Economic Geography 76(3):244-71.

Nyberg, A. \& Rozelle, S. (1999) Accelerating China's Rural Transformation. Washington: The World Bank.

Oi, J. (1999) Rural China Takes Off. Berkeley: University Of California Press.

Ostrom, E. (2001) "Vulnerability and polycentric governance systems", IHDP Update 3/01: 1-4. <http://www.ihdp.uni-bonn.de/html/>

Panagariya, A. (1993) "Unraveling the Mysteries of China's Foreign Trade Regime", World Economy 16(1): 51-68.

Pereira, L., Cai, L, \& Hann M (2003) "Farm Water and Soil Management for Improved Water Use in the North China Plain", Irrigation and Drainage 52(4):299-317.

Pomfret, R. (1996) Asian Economies in Transition: Reforming Centrally Planned Economies. Cheltenham: Edward Elgar.

$<$ www.publications/update/update01_03/IHDPUpdate01_03_ostrom.html>

SEPA (State Environmental Protection Administration) (2002) Report on the State of the Environment in China 2002. Beijing: Environmental Information Centre (SEPA).

Shu, G., Zhou, Y., Zhang, M. \& Smallwood, K. (2001) “A sustainable agro-ecological solution to water shortage in the North China Plain (Huabei Plain)", Journal of Envrionmental Planning and Management 44(3):345-55.

Tian, W. \& Chudleigh, J. (1999) "China's Feed Grain Market: Development and Prospects”, Agribusiness 15(3): 393-409. 
UNDP (United Nations Development Program) (2002) China Human Development Report 2002: Making Green Development a Choice. New York: Oxford University Press.

— (2004) Human Development Report 2004. Oxford: Oxford University Press.

Varis, O. \& Vakkilainen, P. (2001) "China's 8 Challenges to Water Resource Management in the First Quarter of the 21st Century", Geomorphology 41(2-3): 93-104.

Vermeer, E. (1998) "Industrial Pollution in China and Remedial Policies" The China Quarterly 156 (Special Issue): 952-985.

Wang, M., Webber, M. \& Zhu, Y. (2002a) "Managed Openness: Opening China's Door" in Webber, M., Wang, M. \& Zhu, Y. (eds.) China's Transition to a Global Economy. New York: Palgrave Macmillan.

- (2002b) "China's Puzzle Game: Four Spatial Shifts of Development" in: Webber, M., Wang, M. \& Zhu, Y. (eds.) China's Transition to a Global Economy. New York: Palgrave Macmillan.

Wang, X. \& Ongley, E. (2004) "Transjurisdictional water pollution disputes and measures of Resolution: Examples from the Yellow River Basin, China", Water International, 29(3): 282-289.

Wang, Y. (2003) "Water dispute in the Yellow River basin: challenges to a centralized system" China Environment Series 6: 94-98.

Watson, A., Findlay, C. \& Chen, C. (1996) "The Growth of Rural Industry: The Impact of Fiscal Contracting", in Garnaut, R., Guo, S. \& Ma, G. (eds.) The Third Revolution in the Chinese Countryside. Cambridge: Cambridge University Press: $<$ WDS_IBank_Servlet?pcont=details\&eid $=000009265 \_3970909143002$.>

Webber, M., Wang, M. \& Zhu Y (2002a) "Making Markets" in Webber, M., Wang, M. \& Zhu, Y. (eds.) China's Transition to a Global Economy. New York: Palgrave Macmillan.

_ (2002b) “Knocking on WTO's Door” in Webber, M., Wang, M. \& Zhu, Y. (eds.) China's Transition to a Global Economy. New York: Palgrave Macmillan.

World Bank (2002) China. Country Water Resources Assistance Strategy. Washington: The World Bank East Asia and Pacific Region.

WTO (World Trade Organisation) (2003) International Trade Statistics 2003. Geneva: WTO.

Wu, B. \& Pretty, J. (2004) "Social Connectedness in Marginal Rural China: The Case of Farmer Innovation Circles in Zhidan, North Shaanxi", Agriculture and Human Values 21: 81-92.

Xu, C. (1995) A Different Transition Path. New York: Graland.

Yang, H. \& Zehnder, A. (2001) "China's Regional Water Scarcity and Implications for Grain Supply and Trade" Environment and Planning A 33(1):79-95.

Yang, H., Zhang, X. \& Zehnder, A. (2003) "Water Scarcity, Pricing Mechanisms and Institutional Reform in Northern China Irrigated Agriculture", Agricultural Water Management 61(2): 143-61.

YRCC (Yellow River Conservancy Commission) (2005a) "Development and Utilization of Water Resources". 
- (2005b) Proceedings of the Second International Yellow River Forum on Keeping Healthy Life of the River Zhengzhou: YRCC.

Zhang, H., Wang, X., You, M. \& Liu, C. (1999) "Water - yield relations and water-use efficiency of winter wheat in the North China Plain", Irrigation Science 19: 3745.

Zhen, L. \& Routray, J. (2002) "Groundwater Resource Use Practices and Implications for Sustainable Agricultural Development in the North China Plain: A Case Study in Ningjin County of Shandong Province, PR China", Water Resources Development 18: 581-93. 